\title{
Stress and Coping Strategies of Trainee Counsellors during COVID-19 Movement Control Order
}

\section{Nasrudin Subhi, Fatin Nabihah Omar \& Mohd Suhaimi Mohamad}

To Link this Article: http://dx.doi.org/10.6007/IJARBSS/v11-i6/10226 DOI:10.6007/IJARBSS/v11-i6/10226

Received: 18 April 2021, Revised: 21 May 2021, Accepted: 02 June 2021

Published Online: 15 June 2021

In-Text Citation: (Subhi et al., 2021)

To Cite this Article: Subhi, N., Omar, F. N., \& Mohamad, M. S. (2021). Stress and Coping Strategies of Trainee Counsellors during COVID-19 Movement Control Order. International Journal of Academic Research in Business and Social Sciences, 11(6), 958-968.

\section{Copyright: (c) 2021 The Author(s)}

Published by Human Resource Management Academic Research Society (www.hrmars.com)

This article is published under the Creative Commons Attribution (CC BY 4.0) license. Anyone may reproduce, distribute, translate and create derivative works of this article (for both commercial and non-commercial purposes), subject to full attribution to the original publication and authors. The full terms of this license may be seen at: http://creativecommons.org/licences/by/4.0/legalcode

\section{Vol. 11, No. 6, 2021, Pg. 958 - 968}

Full Terms \& Conditions of access and use can be found at http://hrmars.com/index.php/pages/detail/publication-ethics 


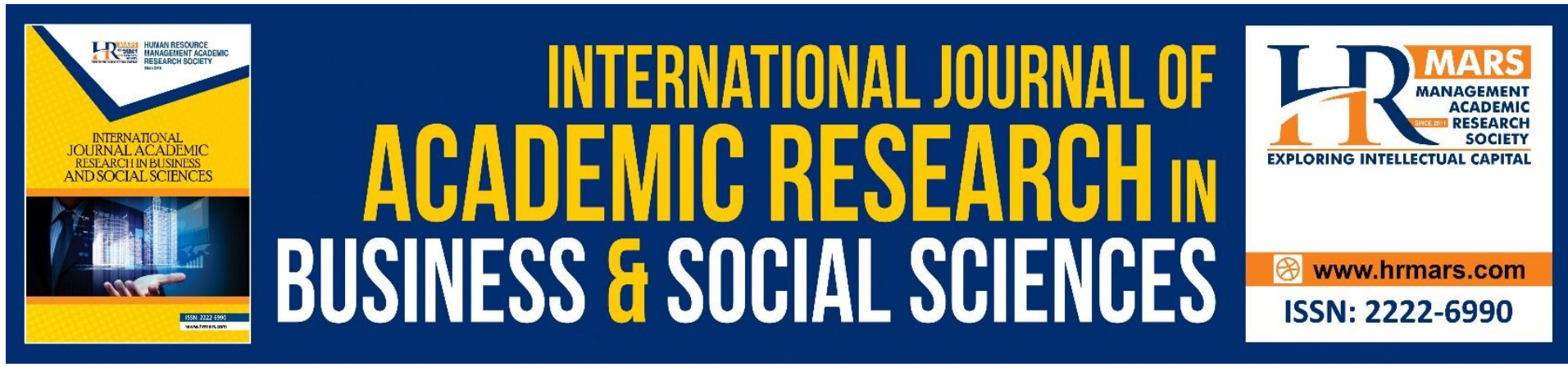

\title{
Stress and Coping Strategies of Trainee Counsellors during COVID-19 Movement Control Order
}

\author{
Nasrudin Subhi, Fatin Nabihah Omar \& Mohd Suhaimi \\ Mohamad \\ Centre for Research in Psychology and Human Well-being, Faculty of Social Sciences \& \\ Humanities, Universiti Kebangsaan Malaysia \\ Email: msuhaimi@ukm.edu.my
}

\begin{abstract}
The purpose of this study is to examine the association of coping strategies and resilience with stress of trainee counsellors during the MCO COVID-19. A survey method by distributing the questionnaire online was conducted among 151 final year students in counselling from public and private universities in Malaysia. They were regard as trainee counsellors undergoing internship in several oraganizations. The instruments used in this study were the Perceived Stress Scale 10 (PSS10) and Brief COPE Scale. The results showed that the level of stress trainee counsellors' acquired during MCO COVID-19 was average. While there was no difference in the level of stress based on gender and level of education of trainee counsellors during $\mathrm{MCO}$ the findings showed significance in relationship between problem-focused coping, emotion focused coping and avoidance coping with perceived stress. Based on the findings obtained, this study is able to provide information and knowledge to trainee counsellors to identify the best way of self-care for themselves. Furthermore, the information generated in this study can serve as a guide and reference by those who are interested to design and implement intervention programs or stress management activities of counselling students' self-care as preparation in facing unexpected circumstances such as the COVID-19 pandemic.
\end{abstract}

Keywords: Stress, Coping Strategies, Trainee Counsellors, COVID-19

\section{Introduction}

The declaration of the Novel Coronavirus 2019 or COVID-19 pandemic by the World Health Organization (WHO) on 11 March 2020 (WHO 2020) has given concern and fear to the Malaysian community. This is because the COVID-19 pandemic has spread so widely across national borders and even has the effect of increasing fatality in death toll. To address the spread of this epidemic, the Malaysian government has taken strict measures such as travel restrictions, quarantine, movement control, postponement and cancellation of events, as well as the closure of facilities. The Movement Control Order (MCO) is among the most important measures in tackling the spread of the COVID-19 pandemic. Although these efforts benefit society in general, but in particular the psychological effects on individuals such as 
symptoms of depression, anxiety, panic and even stress cannot be ignored. Studies on stress and coping strategies among trainee counselors during the COVID-19 Movement Control Order (MCO) are very important to produce professional counsellors who have a high level of emotional, physical and mental well-being. This is in line with the Malaysian Board of Counsellors' Code of Ethics for Counsellors stated in Part C: Professional Responsibilities which requires counsellors to perform self-care activities to maintain and cultivate emotional, physical, mental and spiritual well-being so that counsellors can perform their professional responsibilities in the best possible way (Malaysian Board of Counselors, 2011).

The enforcement of the Movement Control Order (MCO) that started on March 18, 2020, also has a psychological impact on various levels of society, including trainee counsellors. Trainee counsellors are considered as the nation's human capital and prospective counsellors who will venture into the field of counselling profession. Working as counsellor can easily be prone to stress and fatigue. If the situation is not taken cared for thus it can also have affects on the quality of counselling services provided to clients. Although most studies focus on stress among qualified professionals, trainees in the profession may be more vulnerable due to the stress symptoms are more likely to increase during training. Jamiah et al (2019) stated nine different types of stress that include eustress, distress, neustress, acute stress, chronic stress, chronic acute stress, reactive stress, endogenous stress and psychosis stress. Each one of these stress is different from one to the other in the levels and discriptions. Stress is divided into three levels, namely low, medium and high. This stress is measured through the trainee counselor's perceptions or expectations of stress based on feelings and thoughts after going through an unexpected and uncontrollable event. Low stress levels may reflect MCO due to COVID-19 is not significantly affecting trainee counsellors in terms of emotional, physical and mental health. In other words, this may reflect that their practical training is progressing well. While high levels of stress indicate that trainee counsellors are tremendously affected by the situation thus may tend to cause trainee counsellors to be less motivated and worried about their practical training that is likely to cause delay.

Work stress is a common thing experienced by human beings in daily life and often strikes society today. According to Dewan Bahasa dan Pustaka (2007), stress is a state of restlessness, anxiety and tension due to mental or physical stress. Based on the Transactional Theory introduced by Lazarus \& Folkman (1984), coping refers to the way of thinking and behavior shown by individuals while in stressful situations regardless whether the stress is internal or external. There are three constructs of coping strategies namely problem-focused coping by overcoming stress directly, emotion-focused coping - by controlling emotions arising as a result of stress (Biggs et al., 2017) and the third is avoidance-focused coping - strategies describing action and cognitive changes made to avoid stressful situations (Endler, 1997). Based on the study by Sundarasen et al (2020) with regard to the psychological impact among university students in Malaysia during COVID-19 and MCO, they found that there is indeed an influence of stress and anxiety among students and also the lack of coping strategies used in dealing with their stress levels. Since the trainee counsellors are also considered as university students, the researchers felt the importance of a study done on trainee counsellors to see their level of stress and coping strategies used by them in dealing with this stressful situation. Skill in managing stress and effective coping are vital skills needed to be inculcated in training in order to prepare trainee counsellors to deal with a variety of stressful situations during this pandemic period. Thus, the objective of this journal article is to identify the stress level of 
trainee counsellors during COVID-19 MCO as well as comparing it based on several demographic factors. In addition, the objective of this journal article is also to identify the relationship between trainee counsellors' stress and coping strategies during COVID-19 MCO.

\section{Research Methodology}

This study is a quantitative study that uses a survey method by distributing online questionnaires to trainee counsellors. They are those who work as trainee counselors in several institutions and organizations to meet the requirements in acquiring the counselling hours as set by the Malaysian Board of Counsellors and one of the regulation in becoming a registered counsellor. The study subjects consisted of counselling students at the undergraduate $(69.5 \%)$ and master (30.5\%) final year levels from several public $(79.4 \%)$ and private (20.6\%) universities who were undergoing internships. In total, this study involved 151 respondents with a breakdown of 16 males and 135 females. They are divided into four age categories namely $20-29$ years (135 people), 30-39 years (10 people), 40-49 years (4 people) and 50-59 years (2 people). A total of 133 respondents were Malay, 3 Chinese respondents, 4 Indian respondents and 11 respondents were of other races. As this study was conducted during the period of COVID-19 MCO, the method of data collection was conducted through the distribution of questionnaires along with informed consent using Google Form. Announcements are made using Whatsapp application and also email. The selection criteria for respondents must be final year university students majoring in counselling at undergraduate or graduate levels who are undergoing training as a trainee counsellor in any organization during the period of COVID-19 MCO.

A thorough explanation was also included in the questionnaire to avoid any errors in the online filling process. The questionnaire used was divided into four sections: (a) demographics, (b) Perceived Stress Scale (PSS10); this scale consists of 10 items using a 5point Likert Scale namely 0 (Never), 1 (Almost never), 2 (Sometimes), 3 (Quite often) and 4 (Very often) while section (c) Brief COPE; this scale has 28 items using a 4-point Likert Scale namely 1 (Never do it), 2 (Rarely do it), 3 (Do it often) and 4 (Do it very often). Respondents were estimated to take about 20 to 30 minutes to complete the questionnaire. Only questionnaires that were completed and qualified for participation in this study were analyzed. After the questionnaire and raw data were returned, all information was analyzed using Statistical Package for Social Science (SPSS) version 26. Statistical methods were used to obtain the frequency distribution, mean, percentage and identify relationships using Pearson Correlation method. In addition, t-test was also used to identify the differences of the factors studied.

\section{Research Findings \\ Stress Level among Trainees}

Table 1 shows the mean values for the stress levels of the trainee counsellors. The mean value obtained is $M=19.99$ and the standard deviation is $S D=6.06$. Since the maximum score value for stress score is 40 marks, therefore the value of $M=19.99$ respondents proves that the respondents' stress level is at a moderate level. 
Table 1: Minimum score, maximum score, mean dan standard deviation of stress level

\begin{tabular}{llllll}
\hline Scale & $\mathrm{N}$ & Minimum & Maximum & Mean (M) & $\begin{array}{l}\text { Standard } \\
\text { deviation (SD) }\end{array}$ \\
\hline Stress & 151 & 0 & 39 & 19.99 & 6.06 \\
\hline
\end{tabular}

Based on Table 2, there were 113 trainee counsellors (74.8\%) who reported being at moderate stress level. While the respondents who are in the low and high levels each have the same number of 19 people (12.6\%).

Table 2: Stress levels of trainee counsellors during COVID-19 MCO

\begin{tabular}{llll}
\hline Stress levels & $\mathrm{N}$ & Frequency & Pecentage (\%) \\
\hline Low & 151 & 19 & 12.6 \\
Medium & 151 & 113 & 74.8 \\
High & 151 & 19 & 12.6 \\
\hline
\end{tabular}

The t-test analysis in Table 3 shows the stress level scores of trainee counsellors between male and female. Based on the data shows that there is no significant difference in stress levels between the sexes. The $t$-value for the stress comparison of male trainee counsellors and female trainee counsellors was $t=0.648$ and the significance level was $p=0.52$. This significance level was greater than 0.05 ( $p>0.05)$. Therefore, there was no significant stress difference between male trainee counsellors and female trainee counsellors. The mean stress value of male trainee counsellors was $M=19.06$ while that of female trainee counsellors was $M=20.10$. This means that the mean values for both sexes indicate that the stress levels for male and female trainee counsellors are equivalent.

Table 3: T-test results for intergender stress

\begin{tabular}{llllll}
\hline Gender & $\mathrm{N}$ & Mean & $\begin{array}{l}\text { Standard } \\
\text { deviation }\end{array}$ & $t$ & $\begin{array}{l}\text { Significance } \\
(p)\end{array}$ \\
\hline Male & 16 & 19.06 & 6.17 & -0.65 & 0.52 \\
Female & 135 & 20.10 & 6.06 & & \\
\hline
\end{tabular}

Table 4 found that the t-value for the comparison of stress for bachelor's degree and master's degree is $t=1.04$ and the significance level is $p=0.299$. This significance level was greater than 0.05 ( $p>0.05$ ). Therefore, there was no significant difference in the level of stress in terms of the level of education. The mean value of stress for trainee counsellors at the bachelor's degree level was $M=0.33$ and master's degree was $M=19.22$. This means that the mean values for these two levels of study indicate that the levels of stress for undergraduate and master's degree trainee counsellors are equivalent.

Table 4: T-test results for stress between gender and level of education

\begin{tabular}{|c|c|c|c|c|c|}
\hline $\begin{array}{l}\text { Level } \\
\text { education }\end{array}$ & $\mathrm{N}$ & Mean & $\begin{array}{l}\text { Standard } \\
\text { deviation }\end{array}$ & $t$ & $\begin{array}{l}\text { Significance } \\
(p)\end{array}$ \\
\hline $\begin{array}{l}\text { Undergraduate } \\
\text { degree }\end{array}$ & 105 & 20.33 & 6.23 & 1.04 & 0.299 \\
\hline Master degree & 46 & 19.22 & 5.66 & & \\
\hline
\end{tabular}

Although the results showed no significant differences between gender and level of education, however this study found that significant results were obtained when obversing at the methods used by respondents in solving problems that lead to the stress faced. The results of the correlation test in Table 5 showed that significant values between problemfocused coping strategies ( $p<0.05, r=-0.37$ ), emotion-focused coping strategies $(p<0.05, r=-$ 
$0.42)$ and avoidance coping strategies $(p<0.05, r=0.41)$ with stress. This suggests that there is a significant relationship between the three types of coping strategies with stress levels.

There was a moderately strong negative correlation for both problem-focused and emotional-focused strategies with stress levels. This indicates an increase in the use of problem-focused and emotions-focused coping strategies among trainee counsellors followed by a decrease in the stress levels of trainee counsellors. While there is a moderately strong positive correlation between avoidance-focused strategies with stress levels. This indicates that the more the use of avoidance strategies among trainee counsellors, the higher the level of stress experienced.

Table 5 shows in more detail the coping strategies adopted by the respondents based on the three main coping strategies that focus on problems, emotions and avoidance. Of the 14 subscales tested, nine subscales showed a significant relationship to stress and of these, six were negatively related, namely active action $(r=-0.41, p<0.01)$, planning $(r=-0.37, p<0.01)$, positive evaluation $(r=0.33, p<0.01)$, acceptance $(r=0.28, p<0.01)$, religion $(r=0.35, p<0.01)$ and emotional support $(r=0.21, p<0.05)$. While the remaining three subscales were positively related namely denial $(r=0.27, p<0.01)$, behavioral withdrawal $(r=0.44, p<0.01)$, and self blame $(r=0.41, p<0.01)$. This study found that the other five subscales, namely social/instrumental support, humour, distraction, expression of feelings also, alcohol and drug consumption did not have a significant relationship with the stress level of trainee counsellors. 
Table 5: The results of a three -dimensional correlation test along with 14 subscales of coping strategies with stress levels

\begin{tabular}{|c|c|c|c|}
\hline Stress levels & $\begin{array}{l}\text { Pearson } \\
\text { Correlations }\end{array}$ & $\begin{array}{l}\text { Sig } \\
\text { tailed })\end{array}$ & $\begin{array}{l}\text { Level of relationship } \\
\text { strength }\end{array}$ \\
\hline $\begin{array}{l}\text { Problem-focused } \\
\text { strategies }\end{array}$ & $-0.37^{* *}$ & 0.00 & Moderately strong \\
\hline Active action & $-0.41 * *$ & 0.00 & \\
\hline Planning & $-0.37 * *$ & 0.00 & \\
\hline Social/instrumental support & -0.12 & 0.16 & \\
\hline $\begin{array}{l}\text { Emotion-focused } \\
\text { strategies }\end{array}$ & $-0.42 * *$ & 0.00 & Moderately strong \\
\hline Positif evaluation & $-0.33 * *$ & 0.00 & \\
\hline Acceptance & $-0.28 * *$ & 0.00 & \\
\hline Humour & -0.10 & 0.23 & \\
\hline Religion & $-0.35 * *$ & 0.00 & \\
\hline Emotional support & $-0.21^{*}$ & 0.11 & \\
\hline
\end{tabular}

\begin{tabular}{llll}
\hline Avoidance coping strategies & $0.41^{* *}$ & 0.00 & Moderately strong \\
\hline Distraction & -0.03 & 0.73 \\
Denial & $0.27^{* *}$ & 0.00 & \\
Expression of feelings & 0.10 & 0.25 \\
Alcohol and drug & 0.15 & 0.07 \\
consumption & & \\
Behavior withdrawal & $0.44^{* *}$ & 0.00 \\
Self-blame & $0.41^{* *}$ & 0.00
\end{tabular}

**Significant correlation at the 0.01 level (2-tailed)

*Significant correlation at the 0.05 level (2-tailed)

\section{Discussion}

This study was conducted to determine the level of stress of trainee counsellors during COVID-19 MCO. The results of the study found that the level of stress for 151 trainee counsellors was at a moderate level of 74.8 percent, while as many as 19 percent, respectively, were at a high and low level. The findings of the study have shown that there is no significant difference between the levels of stress experienced by trainee counsellors according to gender. These findings are in line with the study conducted by Azizi et al (2010); Cao et al (2020); Norazila et al (2018); Zhang and Ma (2020). However, it differs from the study of Rogowska et al (2020) who found that female students' stress levels were higher than males in terms of physical health, anxiety, and stress. Furthermore, women express more emotions than men (Babore et al., 2020). Therefore, the researcher thinks that this difference may be due to differences between cultures and the number of unequal respondents between genders for the current study.

Furthermore, this study also found no difference between the stress levels of trainee counsellors according to the level of education. This study is in line with the study of Aslan et al. (2020) who found that the level of stress acceptance among university students in Turkey during COVID-19 was similar despite different levels of education. The researcher thinks that 
the results of the current study which proves that there is no difference in the stress of trainee counsellors according to the level of study is because this study involves students in the final year and undergoing practical training. For the researchers, it is desirable for them to have the same level of stress because they have the same goal where they have to accumulate hours of face-to-face counselling sessions even at a time when the COVID-19 pandemic is taking place. Their failure to accumulate counselling hours as required by the Malaysian Board of Counselors (LKM) will result in them having to extend their period of study. These actions tend to increase the level of stress that needs to be borne. It has been suggested that the greatest stress occurs towards the later years of university education, probably due to concern about what the future behold as well as fear of failure being the most stressful thing among students (Shamsuddin et al., 2013).

Additionally, this study shows that there is a significant relationship between problemfocused coping strategies with the level of stress received by trainee counsellors. The results of the study are in line with the study conducted by Munusamy \& Assim (2019) where problem-focused coping strategies according to active and planning coping subscales have a relationship with stress levels. The study is further supported by a study by Maclntyre et al. (2020) where there is a relationship between planning and stress. Moreover, the results of the study also found that there was a significant negative relationship between stress and emotion-focused coping strategies for the subscales of positive evaluation, acceptance, religion and emotional support. This indicates that the use of high coping in terms of positive evaluation, acceptance, religion and emotional support resulted in a decrease in the stress levels of trainee counsellors and vice versa. This is in line with the study of Babore et al. (2020) who found that low positive ratings predicted higher levels of stress. Even Fauziah et al. (2020) have also proven that there is a relationship between religious action and the level of stress that individuals use a lot of spiritual approaches such as praying and performing worship. The existence of a relationship between stress and coping through the religious subscale is also evidenced by the study of (Umucu and Lee, 2020).

Moreover, this study found that there was a significant positive relationship between stress and avoidance coping strategies for the subscales of denial, behavioral withdrawal, and selfblame. This study was supported by Aniza et al (2016) who proved that the use of high coping strategies for denial, behavioral withdrawal and self-blame has led to increased stress levels as well. The findings of the study are also further supported by the study of Macintyre et al. (2020) as well as the study of Umucu and Lee (2020) who showed that the six subscales under the avoidance coping strategy were significantly correlated with stress. However, the findings of the study also prove that there are three subscales of avoidance action that are not correlated with stress, namely distraction, expression of feelings also alcohol and drug consumption. This study contrasts with the study from Kumanova and Karastoyanov (2013) where individuals who are more frequently used avoidance strategies such as the expression of feelings experienced more stress.

\section{Conclusion and Implications}

Based on the findings and discussion of the study, the researchers can conclude that the stress levels of the trainee counsellors were at a moderate level during MCO. The stress levels of trainee counsellors were also similar in terms of gender and level of education. At the same time, this study has successfully demonstrated the relationship of coping strategies to trainee 
counsellors' stress during COVID-19 MCO. Trainee counselors have used various types of coping strategies in coping with their stress such as problem-focused, emotion-focused and even avoidance strategies. This study has implications for trainee counsellors in providing information and knowledge to them to identify the best way of self-care for themselves. Selfcare is very important for counsellors to maintain and cultivate their emotional, physical, mental and spiritual well-being so that they can perform their professional responsibilities to the best of their ability. Second, the contribution of information and results of this study is able to make counsellor educators provide students with more effective stress management skills. It is also an initial preparation for unexpected situations such as the COVID-19 outbreak. This study also allows the academic management of the faculty at the university to plan and design programmes to improve the positive personality among counselling students by emphasizing the concept of hardiness of a counselor. In addition, the implications of this study can be used by the Malaysian Board of Counselors (LKM) to provide appropriate syllabus, programmes, courses and modules to professional counsellors in preparation for the prolonged situation of COVID-19. LKM's initiative in improving the competence of counsellors should be given special attention to psychological well-being to encourage prospective counselors to be strong and able to maintain good personal and mental health.

\section{References}

Aniza, I., Sana, T. A., Ahmad, T. J., Chiew, W. L., \& Jamsiah, M. (2016). Stress level and the common coping strategies among international postgraduate students at Universiti Kebangsaan Malaysia Medical Centre (UKMMC), Cheras, Kuala Lumpur, Malaysia. ASEAN Journal of Psychiatry, 17(1), 9-20.

Aslan, I., Ochnik, D., \& Çınar, O. (2020). Exploring perceived stress among students in Turkey during the COVID-19 pandemic. International Journal of Environmental Research and Public Health, 17(23), 1-17.

Azizi, Y., Jamaludin, R., \& Mazeni, I. (2010). Stres dalam kalangan guru sekolah menengah di empat buah negeri di Malaysia. Asia Pacific Journal of Educators and Education, 25, 103136.

Babore, A., Lombardi, L., Viceconti, M. L., Pignataro, S., Marino, V., Crudele, M., Candelori, C., Bramanti, S. M., \& Trumello, C. (2020). Psychological effects of the COVID-2019 pandemic: Perceived stress and coping strategies among healthcare professionals. Psychiatry Research, 293, 1-24.

Bakar, A., \& Ramli, S. (2020). Psychosocial support for healthcare frontliners during COVID-19 pandemic in Malaysia. Asian Journal of Psychiatry, 54, 102272.

Biggs, A., Brough, P., \& Drummod, S. (2017). The Handbook of Stress and Health: A Guide to Research and Practice, HLM. New York: John Wiley \& Sons, Ltd.

Cao, W., Fang, Z., Hou, G., Han, M., Xu, X., Dong, J., \& Zheng, J. (2020). The psychological impact of the COVID-19 epidemic on college students in China. Psychiatry Res., 287, 112934.

Endler, N. S. (1997). Stress, anxiety and coping: The multidimensional interaction model. Canadian Psychology/Psychologie Canadienne, 38(3), 136-153.

Fauziah, I., Athirah, N. A. Z., Nazirah, H., Ezarina, Z., \& Khadijah, A. (2020). Mengukur tekanan dan jenis mekanisme penyelesaian masalah dalam kalangan pelajar Universiti. Jurnal Psikologi Malaysia, 34(2), 1-12. 
Jamiah, M., Hoesni, S. M., MohdNor, H. A., \& Zainun, N. (2019). Stres. In. J. Manap, S. M. Hoesni, H. A. MohdNor (Eds). Pengurusan stres, (pp.13-22). Bangi: Universiti Kebangsaan Malaysia.

Joshi, G., \& Sharma, G. (2020). Burnout: A risk factor amongst mental health professionals during COVID-19. Asian Journal of Psychiatry, 54, 102300.

Khanmohammadi, S., Hajibeglo, A., Rashidan, M., \& Bekmaz, K. (2020). Relationship of resilience with occupational stress among nurses in coronavirus ward of Khatam AlAnbia Hospital, Gonbad Kavous. Neuropsychiatrial Neuropsychologia, 15(1), 1-6.

Dewan, K. (2007). Edisi Keempat. Kuala Lumpur: Dewan Bahasa dan Pustaka.

Kim, B. N., Oh, H. S., \& Park, Y. S. (2011). A study of nurses' resilience, occupational stress and satisfaction. Korean Journal of Occupational Health Nursing, 20(1), 14-23.

Kumanova, M., \& Karastoyanov, G. (2013). Perceived stress and coping strategies. Conference: Third Annual Conference "Education, Science, Innovation". European Polytechnical University Pernik, Bulgaria, Pernik, June 9-10.

Labrague, L. J., \& De Los Santos, J. A. (2020). COVID-19 anxiety among front-line nurses: Predictive role of organisational support, personal resilience and social support. J Nurs Manag, 28, 1653-1661.

Lazarus, R. S., \& Folkman, S. (1984). Stress, appraisal and coping. New York: Springer Publishing Company, Inc.

Lembaga Kaunselor Malaysia. (2011). Piawai dan Kelayakan Latihan Kaunselor. Kuala Lumpur: Lembaga Kaunselor.

Liu, C. Y., Yang, Y., Zhang, X. M., Xu, X., Dou, Q. L., Zhang, W. W., \& Cheng, A. S. K. (2020). The prevalence and influencing factors in anxiety in medical workers fighting COVID-19 in China: A cross-sectional survey. Epidemiology and Infection, 148(98), 1-7.

Ma, Y., Rosenheck, R., \& He, H. (2020). Psychological stress among health care professionals during the 2019 Novel Coronavirus disease outbreak: Cases from online consulting customers. Intensive \& Critical Care Nursing, 61, 102905.

Maclntyre, P. D., Gregersen, T., \& Mercer, S. (2020). Language teachers' coping strategies during the Covid-19 conversion to online teaching: Correlations with stress, wellbeing and negative emotions. System, 94, 102352.

Mahomed, N. J. B., Johari, K. S. K., \& Mahmud, M. I. (2019). Coping strategies and psychological well-being of guidance and counselling teachers in schools. Creative Education, 10, 3028-3040.

Mostafazadeh, A., Ghorbani-Sani, S., Seyed-Mohammadi, N., Ghader-Jola, K., \& Habibpour, Z. (2021). Resilience and its relationship with occupational stress and professional quality of life among nurses in COVID-19 isolation wards. Research Square, 1, 1-11.

Munusamy, A., \& Assim, M. I. S. (2019). Psychology hardiness and psychology well-being of banking sector employees and moderating role of coping strategy. Journal of Social Science and Humanities, 16(1), 1-13.

Norazila, M., Noridayu, I., Atiqah, N. A., Zaleha, Y., \& Jamsari, A. (2018). Hubungan antara beban kerja, faktor peribadi, dan pembelajaran-e terhadap tahap tekanan di kalangan Gen-Y. Jurnal Personalia Pelajar, 21(2), 23-25.

Polizzi, C., Lynn, S. J., \& Perry, A. (2020). Stress and coping in the time of COVID-19: Pathways to resilience and recovery. Clinical Neuropsychiatry: Journal of Treatment Evaluation, $17(2), 59-62$. 
Pourafzal, F., Seyedfatemi, N., Inanloo, M., \& Haghani, H. (2013). Relationship between perceived stress with resilience among undergraduate nursing students. Journal of Hayat, 19 (1), 41-52.

Rogowska, A. M., Kuśnierz, C., \& Bokszczanin, A. (2020). Examining anxiety, life satisfaction, general health, stress and coping styles during COVID-19 pandemic in Polish sample of university students. Psychology Research and Behavior Management, 13, 797-811.

Santhosh, K. R., \& James, J. (2013). The effect of resilience on burnout among the blue collared employees in metal factories. EXCEL International Journal of Multidisciplinary Management Studies, 3(6), 48-55.

Shamsuddin, K., Fadzil, F., Wanlsmail, W. S., Shah, S. A., Omar, K., Muhammad, N. A., ... Mahadevan, R. (2013). Correlates of depression, anxiety and stress among Malaysian university students. Asian Journal of Psychiatry, 6, 318-323.

Sundarasen, S., Chinna, K., Kamaludin, K., Nurunnabi, M., Baloch, G. M., Khoshaim, H. B., Hossain, S. F. A., \& Sukayt, A. (2020). Psychological impact of Covid-19 and lockdown among university students in Malaysia: Implications and policy recommendations. Int. J. Environ. Res. Public Health, 17(17), 6206.

Umucu, E., \& Lee, B. (2020). Examining the impact of COVID-19 on stress and coping strategies in individuals with disabilities and chronic conditions. Rehabilitation Psychology, 65(3), 193-198.

World Health Organization. (1991). Guidelines for the assessment of herbal medicines. Geneva: World Health Organization.

Yildirim, M., \& Solmaz, F. (2020). COVID-19 burnout, COVID-19 stress and resilience: Initial psychometric properties of COVID-19 Burnout Scale. Death Studies, 1-9.

Zhang, Y., \& Ma, Z. F. (2020). Impact of the COVID-19 pandemic on mental health and quality of life among local residents in Liaoning Province, China: A cross-sectional study. International Journal of Environmental Research and Public Health, 17(7), 2381. 